\author{
Renata Majewska \\ NKJO w Bydgoszcay \\ Cecylia Tatoj \\ Uniwersytet Ślaski
}

\title{
SPRAWOZDANIE Z BADAŃ JAKOŚCIOWYCH PROWA- DZONYCH NA ZLECENIE CODN W KLASACH DWUJĘZYCZNYCH Z JĘZYKIEM HISZPAŃSKIM W POLSKICH GIMNAZJACH I LICEACH
}

\begin{abstract}
Report from a qualitative study commissioned by the National Inservice Teacher Training Centre [Centralny Ośrodek Doskonalenia Nauczycieli] and conducted in bilingual classes with Spanish as a second language in Polish junior high schools and high schools
\end{abstract}

The paper presents the results of a qualitative study, contained in the evaluative report prepared in 2008 and commissioned by the National In-service Teacher Training Centre [Centralny Ośrodek Doskonalenia Nauczycieli, CODN]), conducted in bilingual classes with Spanish as a second language in Polish junior high schools and high schools. This report highlights the basic features of these classes in which Spanish is taught as a second language, discusses the basic needs, gives an outline of future recommendations as well as proposes some fundamental changes.

\section{Wstęp}

Celem niniejszego artykułu jest przedstawienie wyników badań jakościowych, prowadzonych w klasach dwujęzycznych z językiem hiszpańskim na poziomie liceum i gimnazjum, zawartych w raporcie ewaluacyjnym ,Sekcje dwujęzyczne z językiem 
hiszpańskim w Polsce" oraz zasygnalizowanie kierunku proponowanych zmian. Raport, sporządzony w roku 2008 przez zespół, w którego skład weszły autorki niniejszego artykułu, jest kontynuacją opisu stanu sekcji dwujęzycznych w polskich szkołach prowadzonego przez Centralny Ośrodek Doskonalenia Nauczycieli (CODN). Poprzednie raporty dotyczyły: sekcji z językiem francuskim (2005) oraz sekcji z językiem angielskim (2008).

W raporcie przedstawiono nauczanie dwujęzyczne w polskich gimnazjach i liceach skupiając się na różnych jego aspektach, aby dać możliwie najszerszy obraz sytuacji sekcji dwujęzycznych z językiem hiszpańskim. Składa się on z dwóch części: pierwsza zawiera badania jakościowe, druga dane ilościowe. Główne cele raportu to: ukazanie specyfiki sekcji dwujęzycznych z językiem hiszpańskim w Polsce, przedstawienie podstawowych cech tych sekcji, omówienie potrzeb w dziedzinie ich funkcjonowania oraz sformułowanie zaleceń na przyszłość.

W niniejszym artykule przedstawimy część pierwsza, w której zawarto dane zebrane na podstawie wizyt monitorujących w jednej trzeciej polskich szkół prowadzących hiszpańskie sekcje dwujęzyczne. Wizyty te składały się z: obserwacji lekcji języka hiszpańskiego, obserwacji przedmiotu niejęzykowego (np. historia, geografia.) prowadzonego w języku hiszpańskim, wywiadzie grupowym z uczniami, wywiadzie grupowym z nauczycielami języka hiszpańskiego oraz przedmiotów niejęzykowych prowadzonych w języku hiszpańskim, wywiadzie z koordynatorem sekcji oraz wywiadzie z niektórymi dyrektorami szkół.

\section{Polski model sekcji dwujęzycznej z językiem hiszpańskim}

Pierwsza polska klasa dwujęzyczna z językiem hiszpańskim powstała w XXIV Liceum im. Miguela de Cervantesa w Warszawie w roku 1991. W dniu dzisiejszym sekcje dwujęzyczne działaja w 5 gimnazjach oraz 14 liceach w Polsce.

Obecnie podstawa funkcjonowania hiszpańskich sekcji dwujęzycznych w gimnazjach i liceach jest porozumienie podpisane 6 maja 1997 roku pomiędzy Ministerstwem Edukacji Narodowej Rzeczypospolitej Polskiej a Ministerstwem Edukacji i Kultury Hiszpanii w sprawie tworzenia i funkcjonowania klas dwujęzycznych z językiem hiszpańskim w liceach ogólnokształcących Rzeczypospolitej Polskiej, organizacji egzaminu dojrzałości dla absolwentów tych klas oraz określenia warunków niezbędnych dla nadania im przez Ministerstwo Edukacji i Kultury Hiszpanii Titulo de Bachiller. Na mocy tego porozumienia jeszcze w tym samym roku rozpoczęto w Polsce tworzenie kolejnych sekcji dwujęzycznych z językiem hiszpańskim. Klasy te zostały wprowadzone najpierw w liceach, a, po reorganizacji polskiego systemu edukacji, także w gimnazjach.

Sekcje dwujęzyczne z językiem hiszpańskim w swej ofercie mają język hiszpański znacznym wymiarze godzin oraz dodatkowe przedmioty związane z wiedzą o kulturze Hiszpanii. W przypadku gimnazjum jest to literatura Hiszpanii; a w przypadku liceum, przedmiot zwany kultura Hiszpanii, obejmujący geografię Hiszpanii (w ok. 30\%), historię Hiszpanii (w ok. 50\%) i historię sztuki Hiszpanii (w ok. 20\%), oraz przedmiot zwany jesylk i literatura hiszpańska, obejmujący wiedzę językoznawczą 
i literaturoznawczą. Są one prowadzone po hiszpańsku przez wykwalifikowanych lektorów - rodzimych użytkowników tego języka, których obecność w polskich szkołach gwarantuje wyżej wymienione porozumienie. Reszta przedmiotów stanowiąca podstawę nauczania, wykładana jest, z nielicznymi wyjątkami, wyłącznie w języku polskim.

Należy podkreślić, że model ten odbiega od modelu sekcji z językiem angielskim, niemieckim czy francuskim, w których przedmioty niejęzykowe nauczane $\mathrm{w}$ języku obcym nie są w tak dużym stopniu związane $\mathrm{z}$ wiedzą o danym kraju. W sekcjach tych w języku obcym przeważnie naucza się biologii, geografii, matematyki, fizyki, chemii i historii. Przedmioty te najczęściej prowadzone są przez polskich nauczycieli posiadających wiedzę z zakresu swojego przedmiotu oraz wysoki stopień znajomości języka obcego. Nauczając w języku obcym używają oni języka jako narzędzia do przekazywania wiedzy, na przykład z zakresu nauk ścisłych. Ponadto, w klasach tych, co jest bardzo istotne, oba języki nauczania - polski i obcy sa powszechnie obecne na lekcji przedmiotu niejęzykowego uczonego dwujęzycznie, co nazywamy mikroprzemiennością języków.

W modelu sekcji dwujęzycznej z językiem hiszpańskim, język jest w stopniu wyższym niż w innych sekcjach powiązany z kulturą. Klasa, poza zdobywaniem wysokiej sprawności językowej, nabywa duży zasób wiedzy na temat Hiszpanii. Język nie jest zatem, jedynie narzędziem komunikacji, lecz także, lub przede wszystkim, nośnikiem kultury. Z drugiej strony, zajęcia z PN prowadzone sa głównie przez Hiszpanów, najczęściej nie mówiących po polsku, stąd niemożliwa jest obecność obu języków na lekcji przedmiotu niejęzykowego. Hiszpańskie klasy dwujęzyczne są pewnym wariantem tzw. makroprzemienności języków, tj. pewne jednostki dydaktyczne $z$ danego przedmiotu nauczane są w jednym języku, a inne w drugim. W hiszpańskich sekcjach dwujęzycznych wariant ten polega na tym, że osobno uczy np. geografii Polak po polsku i Hiszpan po hiszpańsku, przy czym niektóre treści ogólne z tego przedmiotu pojawiają się w obu językach, jednak nigdy języki te nie występują równocześnie na tej samej lekcji.

Należy dodać, że w tylko bardzo nielicznych przypadkach mamy do czynienia z mikroprzemiennością, np. w sytuacji, gdy przedmiot niejęzykowy jest nauczany przez polskiego nauczyciela.

\section{Rok zerowy a nauka w gimnazjum}

W poprzednim systemie edukacji, do roku 2002/2003, wszyscy uczniowie oddziałów dwujęzycznych liceum rozpoczynali naukę od tak zwanego roku zerowego, dodatkowego roku, przeznaczonego głównie na intensywną naukę języka hiszpańskiego. Po reformie, sekcje hiszpańskie wprowadzono w 5 polskich gimnazjach, jednak w większości przypadków licea z sekcjami dwujęzycznymi z językiem hiszpańskim zachowały klasy z rokiem zerowym, aby umożliwić naukę w klasach dwujęzycznych także uczniom, którzy nie uczęszczali do gimnazjum dwujęzycznego.

Rok zerowy, podczas którego język hiszpański nauczany jest w wymiarze 18 godzin tygodniowo, ma na celu przygotowanie uczniów do uczenia się przedmio- 
tów niejęzykowych w języku hiszpańskim. Język jest tu traktowany jako podstawowy pomost do zdobywania wiedzy z zakresu literatury, historii, geografii oraz sztuki Hiszpanii. Nauczanie na roku zerowym daje dodatkowo nauczycielom możliwość dokładnego poznania uczniów i znajomości ich poziomu językowego przed przystapieniem do właściwego nauczania dwujęzycznego. Wiedza ta, jak podkreślaja, jest bardzo cenna na dalszych etapach nauki.

Zajęcia w klasie zerowej prowadzone są najczęściej przez 3-4 nauczycieli, zarówno polskich, jak i rodzimych użytkowników języka hiszpańskiego. W niektórych szkołach zajęcia te w swej strukturze przypominają model stosowany na filologii, tzn. są podzielone na: gramatykę, rozumienie ze słuchu, pracę z tekstem i konwersacje. Warto podkreślić, że nie wszyscy nauczyciele hiszpańskich sekcji dwujęzycznych są zwolennikami takiego podziału.

W gimnazjach natomiast uczniowie przez 3 lata intensywnie uczą się języka hiszpańskiego 6 godzin tygodniowo, a od drugiej klasy także literatury Hiszpanii nauczanej po hiszpańsku. Następnie mogą kontynuować naukę w 3-letnim liceum, w tym przypadku nie uczęszczają do klasy zerowej.

Z wywiadów przeprowadzonych z nauczycielami wynika, że lepszy poziom językowy i ogólny reprezentują uczniowie, którzy ukończyli klasę zerową niż absolwenci gimnazjum dwujęzycznego. Nauczyciele podkreślają, że wybór klasy dwujęzycznej w przypadku liceum jest bardziej świadomy, uczniowie są bardziej zmotywowani do nauki, a uczniowie, którzy po roku zerowym sobie nie radza, zazwyczaj zmieniaja profil. Licealiści wraz z rokiem zerowym zyskuja dodatkowy czas, w którym koncentrują się prawie wyłącznie na języku hiszpańskim. Uczą się szybciej i łatwiej przyswajaja sobie zasady gramatyki hiszpańskiej niż gimnazjaliści.

Oba modele są wartościowe, jednak wymierne efekty w postaci wiedzy umiejętności językowych, mimo tej samej liczby godzin, są inne u uczniów starszych niż u młodszych. Wydaje się, że w wypadku sekcji dwujęzycznej uczniowie klas zerowych potrafią o wiele lepiej wykorzystać szansę nauczenia się języka hiszpańskiego.

\section{Język hiszpański jako obcy czy język hiszpański jako ojczysty?}

Uczniowie sekcji dwujęzycznej w gimnazjum oraz uczniowie klasy zerowej uczą się intensywnie języka hiszpańskiego jako obcego (ELE - język hiszpański jako obcy). Są to zajęcia skoncentrowane na osiągnięciu wysokiego poziomu znajomości języka.

Od klasy drugiej gimnazjum oraz od pierwszej klasy liceum, uczniowie, poza zajęciami językowymi, uczą się przedmiotów niejęzykowych w języku hiszpańskim. W momencie rozpoczynania nauki pierwszego PN sytuacja gimnazjalistów jest zupełnie inna niż licealistów, gdyż ci pierwsi reprezentują wówczas poziom językowy A1/A2 (po roku nauki 6 godzin w tygodniu), natomiast ci drudzy są na poziomie B1/B2 (po roku nauki 18 godzin w tygodniu). 
Z obserwacji przeprowadzonych w liceach na zajęciach $\mathrm{z}$ przedmiotów niejęzykowych po hiszpańsku mamy do czynienia z sytuacją bardzo zbliżoną do naturalnego używania języka przez rodzimych użytkowników (ELM - język hiszpański jako ojczysty). Uczniowie wcale lub bardzo rzadko maja trudności językowe, które musza zostać wyjaśnione przez lektora. Nauczyciele hiszpańscy często trafnie przewiduja, gdzie uczeń może mieć problem i zapobiegają trudnościom. Zajęcia przez nich prowadzone sa zbliżone do prowadzonych w szkołach hiszpańskich, a uczniowie korzystają najczęściej z oryginalnych podręczników hiszpańskich.

Przejście z ELE do ELM jest dla uczniów, jak wynika z przeprowadzonych wywiadów, bardzo naturalne i stanowi wyzwanie, któremu w stosunkowo krótkim czasie są w stanie sprostać. Równocześnie daje dużą satysfakcję i potwierdza wysoki poziom języka, jaki osiągnęli.

\section{Ewaluacja - egzaminy, olimpiada, matura}

Wszystkie szkoły prowadzące sekcje dwujęzyczne z językiem hiszpańskim mają własny, wewnętrzny system sprawdzania poziomu językowego. Uczniowie gimnazjum oraz liceum moga przystapić do egzaminu DELE przeprowadzanego przez Instytut Cervantesa, jest on jednak odpłatny. Istotnym jest, że dotychczas nie było powszechnie stosowanego, specjalnego egzaminu gimnazjalnego z języka hiszpańskiego dla klas dwujęzycznych, a co za tym idzie, na egzaminie końcowym uczniowie tych klas nie mieli możliwości sprawdzenia swojej wiedzy i umiejętności z tego języka.

Należy także podkreślić, że w Polsce dotychczas nie były organizowane olimpiady z języka hiszpańskiego, co sprawia, że uczniowie licealnych sekcji dwujęzycznych czują się dyskryminowani, tym bardziej, że wysokie miejsce w olimpiadzie otwiera przed zwycięzcą bramy wyższych uczelni.

Głównym sposobem oceny umiejętności uczniów z oddziałów dwujęzycznych jest zatem matura. Przy czym uczniowie klas dwujęzycznych mają do dyspozycji kilka wariantów egzaminu maturalnego:

1. Uczniowie mogą zdawać hiszpańską maturę, która, tylko w tym wypadku, kończy się otrzymaniem Titulo de bachiller. Zdają wtedy język hiszpański na poziomie dwujęzycznym, dodatkowo przedmiot nazwany kultura Hiszpanii (w skład którego wchodzi historia, geografia oraz historia sztuki Hiszpanii) w języku hiszpańskim, oraz po polsku geografię lub historię na poziomie podstawowym bądź rozszerzonym.

2. Uczeń może także wybrać język hiszpański jako przedmiot obowiązkowy na poziomie klasy dwujęzycznej oraz pozostałe przedmioty w języku polskim.

3. Inna opcja, to wybór innego języka (np. angielskiego) jako obowiązkowego, a języka hiszpańskiego jako nadobowiazkowego na poziomie rozszerzonym oraz pozostałych przedmiotów w języku polskim. 
4. Nieliczne licea w Polsce także dopuszczają możliwość zdawania niektórych przedmiotów maturalnych w języku hiszpańskim, o ile były one prowadzone przez 3 lata dwujęzycznie. Podobnie jak ma to miejsce w przypadku sekcji z językiem angielskim czy francuskim.

5. Uczniowie, którzy ukończyli pełny cykl kształcenia w liceum dwujęzycznym oraz zdali hiszpańską maturę, otrzymują następujące dokumenty dojrzałości, uznawane w obu systemach edukacji: dyplom ukończenia szkoły ponadgimnazjalnej w oddziale dwujęzycznym, zaświadczenie o zdaniu egzaminu maturalnego w oddziale dwujęzycznym i hiszpański Titulo de Bachiller.

Nauczyciele podkreślają brak wyszczególnienia na świadectwie maturalnym przedmiotów, na które składa się kultura Hiszpanii, a są to, jak zaznaczyliśmy wyżej: historia, geografia oraz historia sztuki Hiszpanii. Równocześnie zwracają uwagę, że matura dwujęzyczna z języka jest trudniejsza niż matura rozszerzona, postulując, by wszystkie wyższe uczelnie miały to na względzie przy rekrutacji ulepszając przelicznik matury dwujęzycznej w stosunku do rozszerzonej.

Dodać należy, że świadectwa maturalne są dostarczane w ostatniej chwili przez OKE, co znacznie utrudnia zapisy na hiszpańskie uczelnie. Innym mankamentem podnoszonym przez nauczycieli sekcji dwujęzycznych jest termin matury dwujęzycznej: w tym roku jest dwa dni pod rząd (język i kultura), po południu i na koniec sesji. Znaczący jest także brak egzaminatorów maturalnych dla klas dwujęzycznych z językiem hiszpańskim.

Warto także podkreślić, że nie są organizowane próbne egzaminy maturalne ani z języka hiszpańskiego na poziomie dwujęzycznym ani z przedmiotu kultura Hiszpanii, co jest dużym utrudnieniem zarówno dla nauczycieli, jak i samych maturzystów.

\section{Zalety i wady sekcji dwujęzycznych w opinii nauczycieli}

Nauczyciele z gimnazjów i liceów z sekcjami dwujęzycznymi z językiem hiszpańskim są zadowoleni z pracy w sekcji dwujęzycznej, przede wszystkim dlatego, że pracują z bardzo zmotywowanymi uczniami, poziom nauczania języka jest wysoki, widza jasne cele swojej pracy, dostrzegają jej efekty, co daje dużą satysfakcję zawodowa. Praca skłania ich do nieustannej refleksji nad metodami przekazywania wiedzy oraz pobudza do samodoskonalenia, natomiast wysoki poziom uczniów sprawia, że nie ma miejsca na rutynę, nauczyciel musi stale dbać o podnoszenie własnych kompetencji językowych. Dodatkowo nauczanie prowadzone jest w małych grupach przy dużej ilości godzin, co sprawia, że nauczyciel ma okazję bardzo dobrze poznać swoich uczniów. Większość z nauczycieli zwraca uwage na prestiż związany z uczeniem w sekcji dwujęzycznej-czuje się bardziej doceniana.

Nauczyciele dodaja, że według nich klasy dwujęzyczne dają jedyną możliwość nauczenia się dobrze języka obcego w polskim szkolnictwie publicznym. Do- 
ceniają równocześnie możliwości studiowania w Hiszpanii, jakie otwierają się przed absolwentami tej klasy - są oni bardzo dobrze przygotowani językowo.

W szkole pracuje kilku nauczycieli hiszpańskiego, co jest sytuacją niespotykaną w innych polskich szkołach, dzięki temu, mogą oni wymieniać się spostrzeżeniami. Dodatkowo maja stały kontakt z hiszpańskimi lektorami, co jest ważne ze względu na możliwość konsultowania wszelkich wątpliwości językowych oraz ze względu na kontakt z żywym językiem.

Nauczyciele podkreślają dobrą współpracę z Biurem Radcy ds. Edukacji Ambasady Królestwa Hiszpanii w Warszawie, która jest delegaturą hiszpańskiego Ministerstwa Edukacji i Nauki w Polsce. Mówią o wizytach przedstawicieli Ambasady w ich szkole, mają dostęp do bezpłatnych szkoleń organizowanych przez Biuro, dostają informację o różnych stypendiach oraz możliwościach uczestniczenia w różnych programach oferujących wyjazdy do Hiszpanii, z których część jest bezpłatna, a ich szkoły są zapraszane do udziału w konkursach literackich i teatralnych.

Nauczyciele są bardzo zadowoleni z materiałów dydaktycznych, które im zapewnia strona hiszpańska, wyposażenie biblioteki, na które dostają pieniądze z Ambasady znacząco wpływa na uatrakcyjnienie lekcji. Równocześnie chcieliby mieć jeszcze większą możliwość korzystania ze szkoleń dla nauczycieli w sekcjach dwujęzycznych, np. z metodyki nauczania języka, organizowanych w Polsce czy Hiszpanii. Niektórzy chcieliby uczestniczyć w specjalistycznych kursach, np. z zakresu filmoznawstwa. Dodatkowo oczekiwaliby wsparcia ze strony Ambasady przy przygotowaniu i organizowaniu wymian międzyszkolnych. Obecnie nauczyciel musi sam znaleźć szkołę w Hiszpanii i w całości zorganizować wyjazd uczniom. Stąd sugestia, by wymiany były organizowane na poziomie bardziej oficjalnym. Dużą rolę Ambasady widzą także w przekazywaniu informacji na temat możliwości studiowania na hiszpańskich uniwersytetach, gdyż spora grupa absolwentów ma taki zamiar i sygnalizuje potrzebę uzyskania dokładniejszych informacji na temat stypendiów i systemu naboru na poszczególne uczelnie.

Zdecydowana większość nauczycieli podkreśla, że programy sekcji z językiem hiszpańskim są zbyt obszerne, uczniowie są zbyt obciążeni praca, co sprawia, że niektórzy z nich decydują się na zmianę profilu. Równocześnie zaznaczają, że poza rozszerzeniami związanymi z językiem oraz kulturą Hiszpanii, nie ma przedmiotów na poziomie rozszerzonym, a co za tym idzie, uczniowie nie mają zajęć, które by ich przygotowały do matury na tym właśnie poziomie. Proponuja, aby przedmioty takie jak historia Hiszpanii poszerzyć o elementy historii powszechnej oraz aby zredukować treści przedmiotów niejęzykowych np. zmniejszyć ilość lektur na literaturze Hiszpanii.

Za poważny problem uważają fakt, że nie ma oficjalnie uznanej przez polski system edukacji funkcji koordynatora sekcji dwujęzycznej z językiem hiszpańskim. Faktycznie pracą każdej z sekcji kieruje koordynator na wyraźną prośbę strony hiszpańskiej. Równocześnie brak ustalonych procedur wyznaczania ko- 
ordynatora, brak opisu zakresu jego praw i obowiązków, a także dodatkowego wynagrodzenia lub obniżenia tygodniowego wymiaru godzin pracy.

Niektórzy nauczyciele dodają, że istnieją duże dysproporcje między wysokością otrzymywanych dodatków do pensji w różnych województwach. Równocześnie podkreślają że według nich wybór podręczników do nauki hiszpańskiego zatwierdzonych przez Ministerstwo Edukacji Narodowej jest zbyt mały.

\section{Zalety i wady sekcji dwujęzycznych w opinii uczniów}

Uczniowie wyrażają duże zadowolenie z możliwości, jakie oferuje im klasa dwujęzyczna z językiem hiszpańskim. Czują, że chodzą do wyjątkowej klasy i zdają sobie sprawę z jej atrakcyjności, często podkreślając prestiż, jaki się z tym wiąże. Dodatkowo wyrażają opinię, że znajomość języka hiszpańskiego jest postrzegana jako elitarna, podczas gdy znajomość innych języków, w tym głównie angielskiego, nie jest dla nikogo zaskoczeniem.

Uważają, że mają bardzo dobrą kadrę, szczególnie podkreślają zalety uczenia się z lektorami hiszpańskimi. Lekcje po hiszpańsku dają im dużą satysfakcję, ponieważ pokazuja jak wysoki poziom znajomości języka osiagnęli w stosunkowo krótkim czasie, pozwalają osłuchać się z językiem, dowiedzieć się różnych ciekawostek związanych z Hiszpanią oraz przygotować się do studiowania w tym kraju. Bardzo dużą wagę przywiązują do faktu, że uczą się nie tylko języka, postrzeganego jako słownictwo i zbiór zasad gramatycznych, lecz także kultury i historii, co, jak wyrażają niektórzy, będzie im bardzo przydatne, gdy pojadą do Hiszpanii. Podkreślają, że jest wielu chętnych do tej klasy, dlatego osoby, które przeszły rekrutację reprezentuja wysoki poziom. Klasa osiaga bardzo dobre wyniki w nauczaniu. Widzą bardzo duże możliwości rozwoju, jakie oferuje im ta klasa.

Pytani o możliwość przystąienia do hiszpańskiej matury, niektórzy uczniowie twierdzili, że jest to szansa sprawdzenia swojej wiedzy oraz wstęp na hiszpańskie uczelnie, i łącza ją z dużym prestiżem; inni natomiast wyrażali opinię, że jest ona „niepotrzebna”, ponieważ nie daje żadnych dodatkowych punktów przy rekrutacji na polskie uczelnie.

Jako wady sekcji dwujęzycznej uczniowie wymieniają bardzo obszerny materiał do przerobienia, dużą ilość zajęć, a co za tym idzie bardzo dużo pracy. Czują się przeciążeni, bardzo późno wracają do domu, mają dużo nauki i pozostaje im niewiele czasu na własne zainteresowania. Proponowaliby inny rozkład przedmiotów, tak, aby lepiej wykorzystać rok zerowy i nie obciążać tak bardzo klas I-III. Niektórzy wyrażają opinię, że mają zbyt duży wachlarz przedmiotów, woleliby mieć mniej przedmiotów, najchętniej humanistycznych, z których mogliby zdawać maturę na poziomie rozszerzonym.

Część uczniów wyraża obawy przed matura, są one dwojakiego rodzaju. Jedni chcieliby zdawać polską maturę na poziomie rozszerzonym, ale nie mają przedmiotów rozszerzonych, muszą zatem uczęszczać na fakultety, a często nie mogą ze względu na to, że ich podstawowe lekcje kończą się zbyt późno. Inni, zainteresowa- 
ni maturą hiszpańska, wyrażają opinię, że dostają za mało informacji na jej temat (uważaja, że takie informacje powinny być im przekazywane już w pierwszej klasie) oraz że przy rekrutacji na polskie uczelnie fakt zdania tak trudnego egzaminu nie jest dodatkowo punktowany.

Uczniowie chętnie wzięliby udział w różnego rodzaju wymianach międzynarodowych szczególnie w ramach programów, które oferują wsparcie finansowe.

\section{Wskazówki na przyszłość}

Omawiany raport, mający na celu przedstawienie sytuacji sekcji dwujęzycznych z językiem hiszpańskim w Polsce w roku 2008, można podsumować kilkoma uwagami, które równocześnie łączymy ze wskazówkami na przyszłość:

1. Odnotowujemy coraz większe zainteresowanie językiem hiszpańskim w Polsce, a co za tym idzie sekcjami dwujęzycznymi promującymi ten język i kulturę Hiszpanii. Należy, zatem, wspierać i stymulować dalszy rozwój sekcji hiszpańskich w naszym kraju.

2. Obecne programy nauczania obowiązujące w sekcjach dwujęzycznych z językiem hiszpańskim wydają się być z jednej strony zbyt obszerne, z drugiej nie przygotowują uczniów do zdawania polskiej matury na poziomie rozszerzonym. Uczniowie mają dużą ilość przedmiotów niejęzykowych w języku hiszpańskim oraz różnych przedmiotów w języku polskim na poziomie podstawowym. Dlatego postulujemy o zredukowanie treści przedmiotów niejęzykowcyh nauczanych w języku hiszpańskim z równoczesnym poszerzeniem oferty $\mathrm{z}$ zakresu przedmiotów niejęzykowych obecnie realizowanych w języku polskim. Dodatkowo niektóre PN prowadzone obecnie po polsku mogłyby być nauczane częściowo w języku hiszpańskim tak, by uczniowie mogli przystąpić do matury rozszerzonej z tych przedmiotów.

3. Dostrzegamy potrzebę pewnych zmian związanych z maturą:

a) powinna być przygotowywana próbna matura hiszpańska;

b) uczniowie i nauczyciele powinni mieć dostęp do egzaminów z matury hiszpańskiej z poprzednich lat;

c) różne części hiszpańskiego egzaminu maturalnego nie powinny odbywać się dzień po dniu;

d) jeśli uczeń zdaje przedmiot nazwany kultura Hiszpanii, to na świadectwie maturalnym powinno być wyszczególnione, że w jego skład wchodza: geografia, historia i historia sztuki Hiszpanii;

e) osoby przystępujące do hiszpańskiej matury powinny mieć możliwość zdawania po polsku różnych przedmiotów, a nie jedynie geografii lub historii;

f) postuluje się także, aby wszystkie polskie uczelnie przy rekrutacji stosowały wyższy przelicznik dla języka obcego zdawanego na po- 
ziomie klasy dwujęzycznej niż stosują dla języka obcego zdawanego na poziomie rozszerzonym.

4. Nauczyciele powinni jak najwcześniej informować uczniów o szczegółach dotyczących matury dwujęzycznej.

5. Konieczne jest wprowadzenie olimpiady z języka hiszpańskiego dającej nie tylko możliwość sprawdzenia wiedzy uczniów sekcji hiszpańskich, ale także oferującej laureatom wstęp na wyższe uczelni.

6. Istnieje potrzeba rozszerzenia wymian międzynarodowych z Hiszpania. Tutaj dostrzegamy dużą rolę Biuro Radcy ds. Edukacji Ambasady Hiszpanii, która może znacznie pomóc w nawiązywaniu kontaktów ze stroną hiszpańską oraz wspierać polskich nauczycieli zajmujących się organizacją takich wymian.

7. W gestii Ambasady oraz CODN widzimy także oferowanie większej ilości szkoleń dla nauczycieli sekcji dwujęzycznych, ze szczególnym naciskiem na dydaktykę nauczania ELE. Warto podkreślić, że takie szkolenia dają dodatkowo możliwość kontaktów nauczycieli, w tym koordynatorów, z różnych szkół w celu wymiany doświadczeń. Interesujące mogłyby być także wymiany międzynarodowe z nauczycielami sekcji hiszpańskich z innych krajów Europy.

8. Warto, aby Ambasada oferowała nauczycielom i uczniom informacje na temat możliwości podejmowania studiów w Hiszpanii tj. ogólnych zasad studiowania w tym kraju, procedur rekrutacji, stypendiach, itd.

9. Należy poszerzyć badania nad różnicami pomiędzy licealistami-absolwentami gimnazjum dwujęzycznego oraz licealistami, którzy ukończyli klasę zerową, w celu dokładnego ustalenia poziomu językowego i poziomu motywacji do dalszej nauki. Badania te powinny wpłynąć na dalsze losy sekcji dwujęzycznej w Polsce oraz zostać wzięte pod uwage przy przygotowaniu strategii edukacji językowej w naszym kraju

10. Wato byłoby przenieść niektóre przedmioty niekończące się maturą z klas I-III do klasy zerowej (np. wiedza o kulturze, przedsiębiorczość, czy przysposobienie obronne) w celu odciążenia uczniów.

11. Postulujemy wprowadzenie do polskiego systemu edukacji oficjalnej funkcji koordynatora wraz z dodatkiem funkcyjnym i/lub zniżka godzin.

12. Wskazane by było zunifikowanie wysokości dodatku funkcyjnego za pracę w sekcjach dwujęzycznych w całej Polsce.

Raport, o którym mowa został przedstawiony radcom do spraw edukacji przy Ambasadzie Królestwa Hiszpanii oraz nauczycielom sekcji dwujęzycznych na kursie dydaktyki języka hiszpańskiego, który miał miejsce w Warszawie w marcu 2009 roku. Rozpoczął on dyskusję w środowisku na temat konieczności wprowadzenia pewnych zmian. Podkreślono fakt, że zmiany są konieczne, a przedstawiciele hiszpańskiego Ministerstwa Edukacji zasygnalizowali ich kierunek. Raport nie był jedynym powodem takiej refleksji i podjętych działań, odzwierciedlił natomiast poglądy wygłaszane przez nauczycieli i uczniów już od pewnego czasu. Dyskusja ta 
spowodowała między innymi, że zostały utworzone grupy robocze, opracowujące nowe programy nauczania.

Już od września 2009 roku nauczyciele literatury pracują według nowych programów. Nie obejmują już one w takim zakresie chronologicznej historii literatury, została także zmieniona lista lektur. Obecnie omawiane są lektury z różnych epok, które łączą wspólne wątki tematyczne. Zmiana ta daje szansę na większy nacisk na doskonalenie samego języka i głębsze przetwarzanie treści niż w poprzednim wariancie.

Przygotowywane są również zmiany w przedmiocie kultura Hiszpanii. W planach ma nastąpić większe powiązanie nauczania przedmiotów historia i geografia w języku hiszpańskim z treściami tych samych przedmiotów uczonych po polsku (więcej historii i geografii powszechnej, mniej samej Hiszpanii).

Zmiany te pociagają za sobą również konieczność dostosowania do nich egzaminów maturalnych, co również ma miejsce.

Została również podjęta inicjatywa zorganizowania Olimpiady Języka Hiszpańskiego, a wniosek w tej sprawie spotkał się z przychylnością MEN. Ponadto znacząco uległa poprawie sytuacja związana z wyborem podręczników do nauki języka hiszpańskiego, gdyż zostały dopuszczone nowe podręczniki zarówno do liceum, jak i gimnazjum.

\section{BIBLIOGRAFIA}

Gajo, L. (red.) 2005. Raport ewaluacyjny- sekcje dwujezyczne zjezykiem francuskim w Polsce. Warszawa: Ambasada Francji w Polsce/CODN.

Marsh, D. (red.) 2008. Profile Raport Bilingual Education (English) in Poland. Warszawa: British Council/CODN.

Tatoj, C. (red.) 2008. Raport ewaluacyjny. Sekcje dwujezyczne zjezykiem hiszpańskim w Polsce. Warszawa: CODN. 
